大阪大学医学部, 第 1 解剖学教室 (主任：高木教授).

I. Dept. of Anat., Med. School, Osaka Univ. (Director:Prof. K.TAKAGI).

腹腔リンパ節の実驗細胞学的研究.

Experimental Cytological Studies of Abdominal Lymph Nodes.

松井清孝 Kiyotaka MATSUI.

[昭和 28 年 3 月 25 日原稿受付. ]

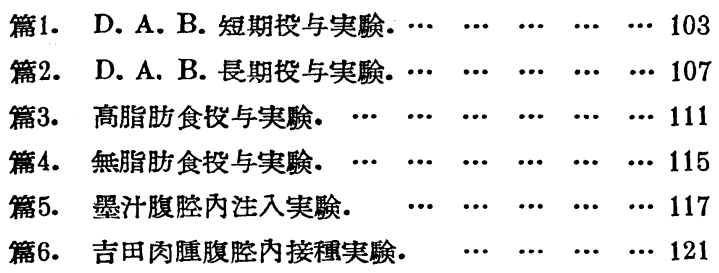

篇 1. D. A. B. 短期投與寞驗.

リンパ節を構成するリンパ組織队化は，あらゆる種類のリンパ球，網內 系細胞を中心とする一連の喰細胞，形質細胞乙び単球との他を混じている. リンパ節組織习括いては，これ等各細胞が生体防禦に重大なる役割を演 ずるるのと考えられているが，その細部に瓦っては佾一致をみない。

余はこれ等の細胞が異常時において如何なる態度をとの組織像の上飞示 すかと云うととに興味を感じた。こっに括いて，ラッテを用い，最も取材 に便利で而も腸管からのリンパを受ける腹腔リンパ節をとりあげ，教室に 颃いて研究されつ」ある D. A. B. (p-Dimethylaminoazobenzene, 即ち Butter yellow, Buttergelb) 投与時に打ける該りンパ節組織像の逐日的動き を追及したのが本研究である.

\title{
I. 宽驗材料之方法.
}

体重約 $100 \mathrm{~g}$ の健康ラッテを4 群に分ち，A群には白米. B 群には白米, オリーブ油，C群には白米，オリーブ油，D. A. B., D 群には白米，オリ 一ブ油，D. A. B.，及び肝末を各々 10，25，40 日間投与した。因みに D. A. B. は $3 \%$ 割合でオリーブ油に溶かし，之を主食に対し $2 \%$ 割に混 ビた，研究材料は每常腹腔リンパ節のなかで，腸間膜根部のリンパ節群の うち最す肥大しているすのを取り, 標本製作には Zenker 氏液固定, ママト キシリンーエオジン染色, Levi 氏液固定, 鉄へマトキシリン染色, 叉 Carnoy 
氏液固定，Feulgen 氏反応，ビロニンーメチルグリューン染色等を用いた。 更飞 imprint 標本，squash 標本をす作製し，May-Giemsa 氏染色を施し参 考にした。

\section{II. 所見}

D. A. B. 10 日投與. 1. リンパ洞には大型の細胞が増数してくる（以 下大型細胞と称する).この細胞の核は形が甚だ種々で，その表面が彎入し， 又綌れ，或は割け目等を現わし，原形質は黄色を帯び，小空胞を多数有す る. 中にはリンパ球又はその他の血球を喰食しているものがある，洞內に はこの細胞のほかに多数の小リンパ球もみられる．この大型細胞のミトコ ンドリフ（以下「ミト」と記す）は微細な桿状又は顆粒状を呈し，胞体內に 均等飞分布している．2. 実質組織にもこの大型細胞が若干入り込んでい るが，桠政めて少数である，この細胞の「ミト」は洞队にあるるのと変りが ない，喰細胞は非常に小さい塵埃様の小片を取り込んでいるが，その数は 少ない。. 牙中心には著変がない。

25 日投與. 1. 洞には多数の小リンパ球及び大型細胞がある. 後者の核 は明るく，歪んでいる．胞体は小空胞を沢山もち黄色を帯びるすの，黄色 顆粒を有するもの，血球又はリンパ球をとるもの等が見られ，洞の稍た。広 い場所にはこの細胞が比較的多い。一般に 10 日例に此してての細胞は大 きく，且つ空胞をるつるのが多くなってきている.「ミト」は微細な顆粒状 で，胞体內に均等に分布している．2. 実質組織には大型細胞が相当入り 込んで怙り，何れも不正形の核をるち，フメーバ様運動を想起せしめる様 な形状を呈し，原形質は黄色を带びて括り，更飞黄色顆粒を有するるのる みられる.この細胞は胞体內に多数の小空胞をるち,「ミト」は小顆粒状を 呈し，均等飞分布している。乙れ等大型細胞が肥満し相寄った形の所謂巨 大細胞が見られる。これ等細胞の中には各くの細胞が個くに并别出来るる の，或は互に融合して一つになったと思われるるの等がある．この細胞は 微細な空胞をるって招り，核は大型細胞にみられるるのと同様である． 3. 牙中心に招いては 10 日例に比して核分裂像が多い，哈細胞は 10 日例より 更に大きな顆粒を攝取し，中にはその細胞の核小体程の大いさを有するる のがある.

40 日投與. 1. リンパ洞は更飞濶く，その中に帯黄色の原形質をるった 大型細胞が夥しく増数し，ために洞はこれ等で充満される場所があると の細胞は黄色乃至黄褐色を帯び，黄色小顆粒をとるるのがみられる．又胞 体には稍そ大きな空胞を多数有し、「ミト」は小顆粒状を主として，これ等 
室胞間隙にみられる．2. 実質組織には大型細胞が更飞深く入り込んでい る.この細胞は叉 25 日例飞和けると同様巨大細胞となるるのが見うけら れる.「ミト」は顆粒状を主とするが，巨大細胞に括いては顆煜状乃至短桿 状をなするのが散在している，何核分裂像は稍々その増数を認め, 又異常 核分裂像を及た。 3. 芽中心Vは核分裂像は愈及增加し, 異常核分裂像も 実質組織に打けるよりる多く認められる。これは染色体橋形成と称される ものである.これて此例して喰細胞の增数も亦顕著で，被嗆食片も大きい． 大型細胞は牙中心暗㲄の周辺飞散在するが，芽中心邖にはみられない。

以上は D. A. B. 投与 40 日汽飞見られるリンパ節の組織像であるが， これと次いで対照群として A， B，D群てついて述へ上う。

$\mathrm{A}$ 群, 即ち白米鶬育群の変化は極めて軽微で常食飼育と大差を認めない.

$\mathrm{B}$ 群, 即ち白米, オリーブ油投与群飞括いては，25日頃からリンパ洞飞 大型細胞の增数が見られ，その他芽中心，実質組繶沉招いても D. A. B. 群と畧々同一の所見を認めるが，一般飞軽度である。 叉，10日例に和い て大型細胞の胞体邖飞多数の空胞をるつものが增数し，巨大細胞も出現す る.これは D. A. B. 25 日例飞打ける所見と畧々一致する。芽中心机け る核分裂像の增数及び異常核分裂像の出現等がみられる。これは D. A. B. 群飞抢ける変化より稍々軽度であるが明らか飞認められる。

$\mathrm{D}$ 群, 即ち $\mathrm{C}$ 群飼料飞肝末を添加したものに招いては, 上記 $\mathrm{A}, \mathrm{B}, \mathrm{C}$ 群 と稍々買った組織像を示す。即ち，1.リンパ洞飞扔いては，大型細胞の 逐日的增数は殆んど見られない，但し，細胞自体の所見，即ち空胞を有し， 黄色を帯びていること, 並に「ミト」が微細な顆粒状乃至桿状を呈し空胞

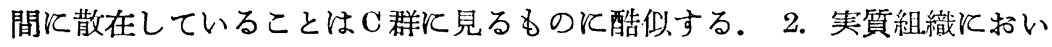
ては 10 日飞既に黄色の原形質を有する大型細胞が現れ，25日，40日と僅 かに增数するが，巨大細胞は見当らない，3. 牙中心では喰細胞が堌数す るほか，正常と変りがない，

\section{III. 總括 と考察.}

以上の所見を D. A. B. 群をびその対热たる各群とついて,、リンパ洞，実 質組織丈び牙中心に括ける組織像を, 大型細胞を中心として次の様沉総括 できる。

1. リンパ洞. D. A. B. 群飞扮いては, リンパ洞は日を迫うて蛋から゙ 〉濶くなると同時に，大型細胞は次第にとの数を增し，漸次洞を満す様に なる，且つ大型細胞自体も次第飞肥大し，その胞体邖飞空胞，大小重々の 黄色顆粒，その他りンパ球，血球及びそれ等の碎片を攝るるのが多くな 
る.「ミト」は最初轻細な桿状型が主であったが，小顆粒状が現れ 40 日頃 には桿状型を凌駕する。

対照群中，白米投与群は認さゃべき変化なく，オリーブ油群においては， D. A. B. 群飞括ける所見が一步呿くれて現れてくる。即ち，D. A. B. 群 の 10 日，25日の所見はほがオリーブ油群の $25 ， 40$ 日に相当する様であ る. 肝末添加群に括いては，わづかに大型細胞の増数が認められるのみで， 数の上からは正常状態と大差がない.

2. 実質組織. D. A. B. 群に括いては，大型細胞は洞に括ける増数に比 例して実質組織にも増数する。この細胞は洞に接近した附近より漸次队部 に向って増数するにつれて黄色顆粒を缷り，喰食により飽満した像を呈す るものが現れる.而して 40 日に至って巨大細胞が出現する。 この細胞の 「ミト」は短桿状乃至顆粒状を呈し, 胞体队飞散在している.

対照群中白米群は認さべき変化なく，オリーブ油群は洞に括けると同様， 一步拉くれてD. A. B. 群の所見を追うている．旰末群に括いては大型細 胞の増数は微ふたるものであるが，細胞の所見は D. A. B. 群にみられる ものに酷似する。

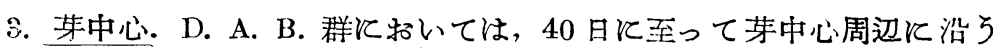
て大型細胞が現れる，少，喰細胞及び核分裂像も日と共に増加する。この 際，喰細胞の被喰食体は次第に大きいものがみられ，核分裂像には染色体 橋形成と称される暴常核分裂像が出現する。

対照群に括いては，オリーブ油群，肝末群とも喰細胞反び核分裂像の増 数がみられるが，異常核分裂像はオリーブ油群に於て少数みられるのみで ある。

腹腔りンパ節はリンパ球の生産及び処理に他の如何なるリンパ節よりる 大なる役割を果すことは既に堀井，玉本両卡の報告しているところである. この腹腔リンパ節が食餌投与によりその組織像と如何なる動きを示すかは 誢だ興味深い。然るところ余の实験の結果によれば，腹腔リンパ節は D. A. B. とオリーブ油を与えたものも，D．A．B. を除いてオリーブ油を与 えたものと本質的には差異のない組織喚の動きを見せた．従ってリンパ節 棈造の動きに対しオリーブ油は大なる意军を有するるのであって，D．A. B. はオリーブ油による影響をわつかに促進せしめているに過ぎないと思 われる. 又 D. A. B., オリーブ油に肝末を加えたるのでは大型細胞の增数 が㵭るしく抑制されることから，肝末の発癌制作用が，腹腔りンパ節では 大型細胞の增数抑制となってあらわれたものと解される。しからば大型細 胞とは如何なる細胞であろらか。この細胞は常食鸰育に拈いても洞にみら 
れるものであるが，各種の飼料によって夫ふの動きを示す点から，腹腔り ンパ節队で重大な役割を演じているにちがいない，而して大型細胞が D. A. B. 群で黄色を帯び，オリーブ油群で黄色をみないのは，或はD. A. B. の色素によるのかもしれない，又この細胞の「ミト」よりみれば，その增 数につれて機能は旺盛となり，肥満型から巨大細胞となるにつれて休止の 状態になることがうから゙党る。

以上の所見は短期投与である為，更に長期投与を行い大型細胞の本態追 及を計画している。

\section{IV. 結語.}

1. 飼料にオリーブ油を混ずるととにより大型細胞は増数する。 もしこ れに D. A. B. を溶かして与えるならば，その増数は一㬝顕㵔である.

2.「ミト」よりみれば，大型細胞はとの增数と共に機能旺盛となり， 肥満型乃至巨大細胞となるに至って休止状を示す。

3. 旰末投与によるものは明らかに D. A. B. による大型細胞の增数を 抑制している.

4. D. A. B. 投与 40 日において，実質組織及び牙中心飞翼常核分裂像 即ち橋形成があらわれる。

\section{篇 2. D. A. B. 長期投與菑驗.}

余はさき飞，D．A. B. 投与ラッテに括けるリンパ節組織像を追及した. その結果, リンパ節組織とは，リンパ洞の拡大，大型細胞の洞反び実質組 織內に招ける増数，巨大細胞の出現，喰細胞の増数，異常核分裂像の出現

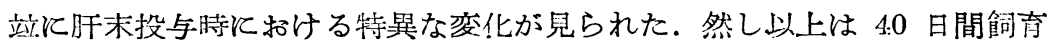
のラッテに特ける所見で，もし長期に互る時にはこれ等の組織像は如何に 変化ずるか。これが本研究を企困した所以である。

\section{I. 宣驗材料と方法.}

体重約 $100 \mathrm{~g}$ 健康ラッテを，短期実験飞括ける場合と同じく4. 群に分ち， 主食として玄米，焦粉を与兄，A群は対照として主食を，而してB群には オリーブ油，C群には D. A. B. を溶かしたオリーブ油，D群には D. A. B., オリーブ油飞肝末を夫ね主食飞加光，各群とも25，49，60，90，120，150日 間飼育した．而してD. A. B. の混入の割合，取材，固定，染色等は前篇 短期实験に打ける場合と同様である。

佾こっに一言したきは，本実験飞拈いては玄米及び少量の焦粉を主食と 
して用いた事である。それは前篇短期実験の壯には白米を用いたが，白米 を連続投与すると次第に含水炭素の代謝が障碍され，加了るに白米による ビタミン缺乏は本实験の結果をして瘾々複雑なるのとなす懼れありと考兄， 今回は玄米食及び蛋白缺乏付耐えるため少量の隐粉を加えた次第である.

\section{II. 所見.}

D. A. B. 25 日及び 40 日投與群. の所見は，前篇の同日数机けるる のより大型細胞の増数が稍々軽度であるのみで，その他は大差がない故， 重複をさけて省畧する。

60 日投與. 1. リンパ洞は拡大して大型細胞の増数が認められる。この 細胞は多数の空胞を有し, 胞体は種々の喰食片をとつている.「ミト」は微 細顆粒状乃至小顆粒状を呈し胞体內飞均等飞分布している，2．実質組織 飞括いても大型細胞の増数が認められ, 胞体は黄色を帯び,「ミト」及び空 胞は洞にみられるものと大差がない，佾この時異常核分裂像として橋形成 がみられる．3．芽中心では大型細胞が明中心の周圍飞接してみられるる のがあるが, 明中心阿にはみない、唋細胞及び核分裂像の増数があり, 又 異常核分裂像もみられる。

90 日投與. 1. 洞に怙ける大型細胞は更飞増数し，胞体內には小顆粒， 小宾胞等がみられ，黄色の顆粒，その他血球等を喰食したものが多い。こ の細胞の「ミト」は微細顆粒状を主とし，短桿状を混じて空胞間隙等に均 等飞分布している．2．实質組織飞扔いても大型細胞は更飞增数と同時に 著るしく肥満し，数ヶの細胞が群をつくって散在している．特に群をつく る傾向は 60 日例比して箸るしくなり，この融领から成り立つと想像さ れる巨大細胞が多い，喰細胞は多数の顆粒をとって招り，その增数がみと められる．3．芽中心では明中心の周圍飞接して大型細胞がみられる．核

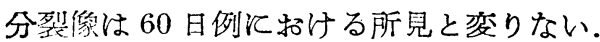

120 日投與. 洞飞は 90 日例飞比して大型細胞が一蜸と增数し，胞体队飞 多数の小空胞及び小顆愔をもつほか，リンパ球その他を呤食している。而 して「ミト」は小顆粒状のものが均等机分布している，2．実質組織では この細胞は更に大きく且つ黄色を帯び，その各々が群をつくり，或は亘大 細胞となって散在する.「ミト」は短桿状或は顆粒状で，稍々集簇的傾向を

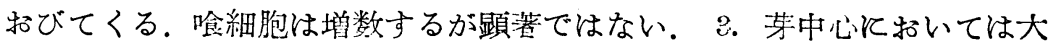
型細胞は明中心の周圍飞接し，或はその䧣款队飞反られる。核分裂像は 90 日例と大差ない。

150 日投與． 1. 洞邖の大型細胞は更に多く，従って洞は著るしく淤大 
する. この細胞は大小種々の空胞を泗しているはか，実質組織內に見るる のと同様に黄色を帯び, 黄色顆粒をとるるのがある. 但し「ミト」は両者 共飞徽細顆粒状乃至小顆粒状で，胞体內飞均等飞分布している．2. 実質 組織には大型細胞が著明に増数し, 而も肥満型で胞体队とは大小璉々の空 胞乃至顆粒をるつ．との細胞の「ミト」は短桿状或は顆粒状で胞体內に散 在している. 巨大細胞す更に大きいものがみられ，1細胞內に 10 数個の核 を算するるのがある，との胞体付《は短桿状「ミト」或は顆粒状「ミト」 が密飞分布している，喰細胞の増数は 120 日例と大差ない，異常核分裂像

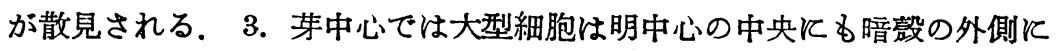

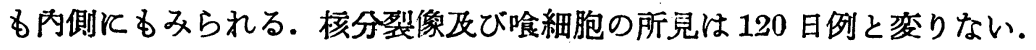
侗，異常核分裂像，即ち橋形成が展ふ見られる。

対照群のらちオリーブ油群飞扔いても各投与日数に応じて D. A. B. 群 と略ね同様の組織変化を起し，たメ゙オリーブ油群にみ゙られるるのは，D. A. B. 群と比して軽度かと思われる程度である. 即ち，D. A. B. 群より稍々 おくれて同一変化過程をとるものの様である.

然ると肝末添加群では前2 群と異り, 洞に抽ける大型細胞の增数は極め て低調で，150日投与例飞招いて漸く D. A. B. 群の 60 日頃飞相当する. 又实質組織では，乙の細胞の肥満型のもの反び互大細胞が 40 日乃至 60 日 頃より現れ，增数且つ肥大するが，D. A. B. 群に比し微々たるるのであ る.

\section{IIr. 櫁括と考察.}

1. リンパ洞 D. A. B. 群飞扔いては, 大型細胞は次第にその数を增し,

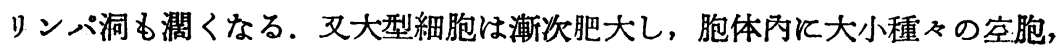
リンパ球及びその他の血球, 種々の大いさの黄色顆粒をるつのが多くな り，これ等が次第にリンパ洞を満すと至る。この細胞の「ミト」は最初微 細な桿状型が主であるが，次第飞短かくなり，遂に小顆粒状となる，但し， 大型細胞の中でる肥満型のものでは短桿状丈は顆粒状の「ミト」が日数と 共に肥厚するのがみられる。

対照群中主食以外飞何も加えないるのでは認むへきき変化なく，オリーブ 油群飞扔いては D. A. B. 群の変化が稍々括くれて現れるのみで，両者の

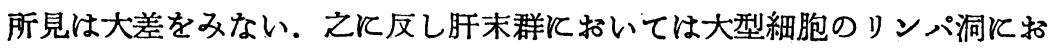
ける増数は極めて微々たるるので，150日と扔いてる D. A. B. 群の 60 日 頃の所見飞相当する。

2. 実質組織. D. A. B. 群と括いては，大型細胞の増数が箸るしく，極 
端に言えばこの細胞が実質組織にとってかわろうとするのではないかと思 われる程である. 大型細胞は最初は洞に接して多くみられるが，その増数 と共にあらゆる場所に現れる。而もこの細胞は経日的に明らかに肥満し, 喰食し，為に核に比して胞体が大きくなる，そして遂にこれ等の融合によ って生じたと思われる巨大細胞が 40 日頃に出現し，その後日を追うて增 大し，核の数も亦多くなる。この巨大細胞の「ミト」は短桿状乃至顆粒状 で，密飞分布している，喰細胞は 120 日頃まで増数するが，以後は変化が ない，その喰食片も逐日大きいるのがみられる。

対照群の 万ち，オリーブ油群にては洞に拈ける場合と略ふ同じく，D. A. B. 群より稍々軽度の変化が実質組織にみられるだけで, 両的に特異な 差異はない様である．然るに肝末群では大型細胞の増数は軽度で，150日 投与で D. A. B. 60 日の所見と酷似する．但し巨大細胞は D. A. B. 群と 時を同じくしてみられる。乙の細胞も逐日増大するが，その数及び大いさ の点では D. A. B. 群に遥かに及ばない, 喰細胞は增数し, 被喰食片も次 第に大きいが，90 日以後は特别の変化をみない。

3. 芽中心. D. A. B. 群に括いて大型細胞は最初見られないが，60日

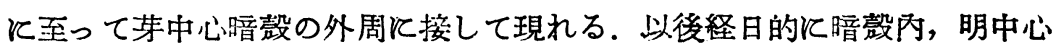
の外周, 更に明中心內にも現れる。とつにみる大型細胞は殆んど単独であ るが，稀には 2 乃至 3 ケ群をつくっている，核分裂像は 60 日頃までは増 数するが，その後は変りがない，異常核分裂像は 40 日以後は常にみられ る. 喰細胞す增数するが，120日以後は明らかでない. 被喰食体は次第に 大きい.

前篇短期実験に打ける如く，本実験にてもオリーブ油によって腹腔リン パ節に大型細胞の増数が認められる. これによって D. A. B. の有無は勿 論, 主食の如何もこの細胞の増数と関係のないことが確認されたが，反面 とは又肝末は大型細胞に関係あることがわかった。

次にこの大型細胞は前実験及び本実験の所見より，腹腔リンパ節におい て何等かの重要な役割を演じていることは容易に想像される. 而して細胞 自身は明らかに喰食能をるっていて，常食飼育では通常リンパ洞に游離し て存在しているが，本実験に括いては実質組織にも現れる.

抑ふリンパ節が生体防衔機能をるつことは, 古くVirchow（1860）の報 告以来現今に至るまで根強く信ぜられているが，その本態に関しては今少 解明に至らない。その詳細はさて持き，こ〉と余の指摘した大型細胞は少 くともリンパ節の防丵機能の一買を荷うものと考えられる. 即ち，この細 
胞が余の両実験に於て増数, 肥満と同時に本来の場所，即ちリンパ洞より 実質組織队化る出現することはリンパ節に流入するリンパに一応の原因を 考えることが出来る。殊にこの大型細胞の変化は最初予期した D. A. B. よりるむしろォリーブ油食によることの大なるを知り，腸管より吸收され た乳ビの队容によって大型細胞が或は動いたのではなかろうかとの考皇に 到详した次第である，この観点から脂肪食実験を企て本細胞の本態を更に 追及したいと念じている.

\section{IV. 結 語.}

1. 本実験に招いても前篇短期実験に打けると同様, 大型細胞の增数に は D. A. B. は殆んぞ関係なく，むしろオリーブ油投与によるととが明ら かである.

2.「ミト」よりみれば，大型細胞はその増数と共に機能旺盛となり， 肥満型乃至巨大細胞となるに至って休止状を示す。

3. 肝末の添加は主食を玄米とし魚粉を混じても明らかに大型細胞の増 数を抑制する.

4. 異常核分裂像は主食を変えても D. A. B. 投与 40 日以後に招いて は常に実質組織及び牙中心にみられる.

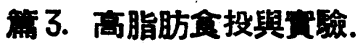

余は前 2 篇に扣いて腹腔りンパ節の洞內にみられる大型細胞はオリーブ 油に溶かした D. A. B. 投与時のみならず，単に主食にオリーブ油を混じ て与えても增数し，早晚これを満し，更に实質組織にも現れ，遂に巨大細 胞となることを報告した．この大型細胞を中心とする組織像の変化は，前 者, 即ち D. A. B. +オリーブ油投与時の方が後者, 即ちオリーブ油のみ を加兊たものよりや小先行して現れるに過ぎないことから，寧ろオリーブ 油が主たる役割を演じているのではなかろうかと考光，今回はオリーブ油 より更に高級脂肪酸たるパルミチン酸を加えた高脂肪食を一定時与え，こ の種大型細胞の態度を追及し，併せてとの時の組織像を検索したのが本研 究である.

\section{I. 惯驗材料と方法.}

体重約 $100 \mathrm{~g}$ の健康ラッテに以下のベる処方の䯩脂肪食を与え， 1 週，2 週，3週及び 4 週目に夫ふ 6 匹づ屠殺し，前回実験と同様の方法により 腹腔リンパ節を鏡検した，因みにパルミチン酸の如き高級脂肪酸を用いた 
理由は低級脂肪酸（例，オリーブ油）では変化は急激に現れるを以て，徐 ふて作用することを予期して高級脂肪酸（例，パルミチン酸）を与えた.

〔註】高脂肪食 (ラッテ 1 吃 1 日分).

$\begin{array}{lc}\text { カゼイン } & 0.5 \\ \text { 溉 粉 } & 8.1 \\ \text { 寒天 (M.C.盐) } & 0.2 \\ \text { 肝 油 } & 0.1 \\ \text { ハル ミチン酸 } & 2.0 \\ \text { 水 } & 18 . \\ \text { V.B1末 } & 0.05\end{array}$

II. 所見.

1 週間投與. 1. リンパ洞に怙いて大型細胞飞増数の兆がみられるが， 未だその数は正常の域を脫しない。たよ゙胞体がわずかに肥大して円形を呈 するものが多くなる程度である，2. 実質組織沈いてこの時已に大型細 胞がみられる.この細胞は核周に大小種々の空胞をるち，喰食片を撮つて いる.3。芽中心には核分裂像の軽度の増数が認められるが，異常分裂像 はない，喰細胞はわつが増数しているが、リンパ母細胞その他には殆ん ぞ変化をみない，次に大型細胞の「ミト」は微細なる桿状乃至顆粒状で胞 体队分布している.

2 週间投與. 1. 洞に抢ける大型細胞は軽度の増数を示し, 特に肥満し た胞体队に多数の空胞をるつるのがふえる，このほか洞內にエオジン好球 がみられる．2. 実質組織飞括ける大型細胞も若干增数すると同時に，胞 体にみられる聜胞は洞內細胞のそれょりる小゙さく且つ少ない，佮胞体には 空胞以外にリンパ球その他の碎片等をとつているるのが見られる．核分裂 像は正常時と殆んど変りがない３．牙中心は 1 週間の所見と大差を認め ない. 次に大型細胞の「ミト」は短桿状又は小顆粒状を呈して胞体に分布 しているが，核の周圄又は小空胞の間に比較的多くみられる.

3 週问投與. 1. 洞は稍々濶くなり，大型細胞の増数も著明となる。而 してその肥満した胞体內には大小種々の空胞を有するほか, リンパ球その 他の碎片をるつものがある。この細胞は同じリンパ節內でも洞により種々 で蹯らにすぎなるのるあるが, 全体としては著るしく増数している，2. 実質組織に打ける大型細胞の増数は前例よりる著明で，更に肥満型が多く 現れる，然し核分裂像には異常を認めない，3．牙中心では核分裂像は増 数しているが，こ〉に於ても異常のるのは認められない. 次に大型細胞の 「ミト」は短桿状又は顆粒状を呈して胞体內に分布し, 種々の喰食片と共 
くみられる。

4 週間投與. 1. 洞に括ける大型細胞の増数は著るしく，特にその胞体 飞小空胞をるつものが甚だ多い，2. 実質組織飞打いても大型細胞の増数 は著明で，胞体は更に肥満し大小多数の空胞をるつている. 佾，この細胞 が数ケ融合したと思われる巨大細胞が現れる，後者は不正形の核及び大小 種々の空胞を有し，核には夫ネ核小体及びクロマチン顆粒をみとめる．核 分裂像の増数がみられるが異常のものはない，3. 牙中心，殊飞明中心に は変りがないが，その外周に巨大細胞が出現する. 次に大型細胞の「ミト」 は短桿状と顆粒状が混じ，更に連珠状をまじえて胞体內に分布している。

\section{III. 總括と考察。}

1. リンパ洞. 洞は 1 週より 4 週にす〉むにつれて㹡大してくる. これ は辺洞よりもむしろ中間洞に抢いて顕著である. 他面大型細胞は次第に その数を増すと同時に, 細胞自体が肥大して円味を帯び, 胞体內に大小種 その室胞をるつ様になり, 又リンパ球その他の碎片をとるるのが多くな る. この細胞の「ミト」は初めは徽細な桿状乃至顆粒状を呈し, 胞体內に 散在しているが，その大いさは大した変りを認めない。

2. 実質組織. 大型細胞の増数は洞に括けるものより軽度である。その 胞体队には大小種くの空胞を有し，日を追うて空胞が多く且つ大きくなる が，洞に括けるものよりも一步括くれている様に思われる. 更にこの種細 胞が漸次肥満型を呈し，遂にはこれ等が相融合して成り立つと思われる巨 大細胞が 4 週に至って現れる. この巨大細胞の「ミト」は大型細胞のそれ と稍々趣を異にし，短桿状又は顆粒状のるのが稍々集簇的に散在する．及 エオジン好球はわつかかがら増数する，次に実質組織に括ける核分裂像る 増数を示すが異常型は全然認めない.

2. 芽中心. 正常時と大差ない外観を呈しているが，喰細胞は僅かに増 数する様である. 叉，4 週になると明中心の周葍に巨大細胞が現れる. 其 の他核分裂像の増数は認められるが，異常核分裂像には接しない。

これを要するに，ラッテに高脂肪食を与えると腹腔りンパ節は肥大す る.これと同時にリンパ洞から実質組織飞瓦って大型細胞が増数する.こ の細胞は次第に增大して円味を帯び，內に多数の空胞をもつ様になる，か くて 4 週頃には実質組織に巨大細胞が出現する.

生体にパルミチン酸による高脂肪食を与えると，何等かの異常がおこる ことは考えられるが，この場合の肝については既に広瀨 (1952) 飞よつて 
報告されている，今，氏の所見を参照して，余の腹腔りンパ節に怙ける組 織細胞学的変化を明らかにしたのが本実験である。

さて，腹腔リンパ節は上記載の如くこの場命にも前篇 D. A. B. 及びオ リーブ油投与実験に和けると同様に腫大する. 従ってこの腫大は飼料中の オリーブ油が分解し，腸管より吸收されて乳ビに混じ，遂に腹腔リンパ節 に流入して之に反応を起させた故であるとの余の考えは本実験によつて更 そ立証されたと信ずる，何となればその組織像は全く前同様で洞の㹡大及 び大型細胞の増数がその主体をなしているとよる.

余はこ〉に大型細胞の成り立ち, 増数及び肥満とい5点について吟味し てみたいと思う。抑々余のいう大型細胞は, 洞又は実筫組織に存在する細 網織細胞と異り，細網織繊維を伴わず，又その細胞の輪廓も明膫でないこ とが多い，而して胞体は土オジンに淡染し，核は多くは不形で 2-3の核 小体及びクロマチン顆粒をるつている. 文献によれば，この細胞は多くの 人々によつて細網織細胞、網状队皮細胞或は組織球等と呼ばれてきたもの と同一のものと考元るが，これ等先人の呼称は不適当と思われる。何とな ればこの細胞は高脂肪食を与えると次第に肥大して円味を帯び，胞体队に 空胞が増加する. 又「ミト」は稍々肥厚して顆粒状のものが桿状形を资駕 する.このことは正常時に網の目をつくっている細網織細胞が，流れくる リンパイ対応して斯くなったものではなかろらか．換言すれば高脂肪食時 のリンパが細網織細胞を剌㦸して，色くのるのを喰食させ漸次肥満し，遂 に網の目から外れて細網織繊維を失い完全に游離したるのと考えられる幾 多の所見に接する.これが本細胞を細網織細胞と区別してあえて大型細胞 と呼ぶ所以である. 清野は本細胞を組織球と考えて括られるが，氏の研究 は專ら超生体染色によったるので，リンパ節內に打ける検索は等闑に附さ れている，又，近時天野は本細胞を単球系の中に含めている様であるが，

これはまだ研究の余地があると思う。

以上の如く余の所謂大型細胞の本態については稍々解明の域に近づいた が, この結論には倘飛躍があり, 且つ巨大細胞については幾多の不明の点 が残されているので，無脂肪食実験を企図し更に一步を進めたい。

\section{IV. 結箈.}

1. 高脂肪食投与によっても大型細胞はリンパ洞立地実質組織內に増数 する. 而してその外観站に內部榡造は, 前篇低脂肪食（オリーブ油）時の それと完全に一致する。

2.この種大型細胞は細網織細胞が漸次機能を高め，肥大し遊離したも 
のと思われる。

3. 高脂肪食投与が 4 週に至ると実験組織队飞巨大細胞が出現する.

\section{篇 4. 無脂肪金投與实龭.}

余はさきに D. A. B. 投与实験飞引続いて高脂肪食実験を行い，腹腔り ンパ節組織像の動きを詳細観祭した. その結果，D. A. B. 投与実験にお ける大型細胞の増数及び実質組織への出動はオリーブ油によることが略々 確実となった。こ」に於てその反証として無脂肪食で飼育した時の腹腟り ンパ節の組織像が必要となってきた。本実験を企図した所々は実にこっに ある。

\section{I. 家蛤材料と方法.}

前諸実験同様に体重的 $100 \mathrm{~g}$ の健康ラッテを次の処方による無脂肪食に て， 1 週， 2 週，3 週，4 週及び長期実験として 2 ケ月，3 ケ月間飼育し た.

取材，固定，染色等は前諸篇と同様である.

〔铑〕無脂助食 (ラッテ 1 匹 1 日分).

\begin{tabular}{|c|c|}
\hline 唄脂カゼイン. & 1.47 \\
\hline 溉粉 & 6.08 \\
\hline 寒天 (M.C.揾) & 0.2 \\
\hline 水 & 10. \\
\hline V. B & 0.05 \\
\hline
\end{tabular}

\section{II. 所胃}

本実験に括ける 1 週，2週，3 週例の組織像は，対照としての常食飼育 と格別の相違点を発見するに至らなかった故，こ小には省畧する.

30 日投與. 1. リンパ洞には大型細胞がみられるが，増数の傾向はない。 核は多くは円形邓は楕凸形に近い形を有し，著るしく歪んだすのはみない。 而して大型細胞で比較的肥大したものでは小宾胞を多くるち, 然らざるす のでは空胞は少ないか或は殆んど之を欠いている. 叉「ミト」は小顆粒状 乃至短桿状で，正常時に比して稍々その数が少ない，洞にはこの他エオジ ン好球が多数みられる．2. 実質組織には大型細胞は全然みられない。た よ゙リンパ球が多少減少し明調の度が稍々高い。このことは核分裂像の少な いことと相俟ってリンパ節機能の低下を思わせる．3. 牙中心には特に著 変なく喰細胞す少ない。

60 日投與. 1. 洞は前者に比し狹く，大型細胞は勿論りンパ球も少数認 
めると過ぎない，次に大型細胞の核は種々で，高度に歪んだるのるあり， 又「ミト」はその数少なく形不正で柾に分布している，2. 実質組織には 著変なく，前例同様大型細胞をみないが，本例と於て初めててれの肥満型 の細胞が数ヶ群集しているのを散見した. この細胞は黄色を゙帯び小空胞を 有している. 3. 牙中心飞招いては少数の大型細胞が明中心の周圍に接し てみられる。この部に抢ける核分裂像は增数し異常のるのが多い，喰細胞 は増数の傾向がある。

90 日投與. 1. 洞に括いては依然として大型細胞の増数はみない. 又と の細胞の形状には特に変つた点はない。この時の「ミト」は微細顆粒状又 は桿状を呈し，小空胞と共に存在する．その数は少なく，殆んど「ミト」 のみえない細胞も多い，2. 実質組織飞抢いては大型細胞は認められない が，前例飞みた肥満型の細胞及びこれ等の融合したと思われる巨大細胞が 出現する，この細胞は黄色を帯び且つ小室胞业飞小顆粒をるっている．核 分裂像の数は 60 日投与例と変らないが異常のるのが多い，3. 牙中心の 明中心の周圍飞大型細胞がみられることも前例と変りない，これは実質組 織の肥満型細胞と同じく黄色を带び, 黄色顆粒と小空胞を有し, 叉これ等 が数ケ融合した様な巨大細胞もみられる，核分裂像の増数は軽度で，中に は異常飞属するるのがある。

\section{III. 禗括と考察.}

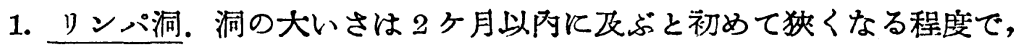
先づ正常の域を脫しないと言える. 而して本実験で特筆すべきは全斯間を 通して余の所謂大型細胞つ增数がみられないことである. 次に大型細胞は 一般に室胞は少ないが, 肥大したものでは室胞が多い. 又「ミト」は微細 な顆粒状乃至短桿状であるが, 形不正なるのが多く, 而る経日的にその数 は少なくなる様に思われる. 特飞 90 日になると多数の徽細茎胞と共飞極 めて微細な顒粒状のるのが極く少数みられるに過ぎない，以上の所見によ ってての時の大型細胞は積極性にそしいことが窺える.

2. 実質組織. 大型細胞怯全例飞於て之をみない. 然し，60日飞和いて はこの細胞の肥満型のるのが現れるほか，90日となるとこれ等の融合とよ って生じたと思元る巨大細胞が出現する.これの特徽は胞体が黄色を呈 し，黄色顆粒を有していることである，又実質組織における核分裂像の増 数はみないが, 異常型が漸增する。

3. 芽中心. 大型細胞は 60 日飞招いて明中心の周圍飞現れ，90日飞招 いて同じ場所に互大細胞がみられる。この部に括いても核分裂像の增数は 
軽度であるが，異常のものが次第に多くなる傾向を示している。

本実験は上記載の如く高脂肪食実験飞打ける所見が，果して高脂肪食飞 特異なるのか否かを決定するるのとして企てたるのであって, 前篇所見と 対照して茥だ興味のある結果を得たと信ずる，即ち，大型細胞がリンパ洞 立に実質組織においてその増数をみないことで，これは高脂肪食実験と全 く対踣的であって，腹腔りンパ節を通過するリンパの相違を物語っている ものと考劣る. 次に 60 日及び 90 日に至って現れる肥満型及び巨大細胞は 高脂肪食の場合にもみられたが，その細胞成分に於て本実験のものと多少 の相違はある。然し本実験の如く大型細胞が洞立に䒠質組織に増数しなく ても，大型細胞の肥満したと思えるもの及び巨大細胞が出現することか ら，必らずしも食慨に括ける脂肪の有無に原因するとは言えない，然らば 何故これら正反対の両実験飞沶いてか〉る肥満型站に巨大細胞が現れるの であろうか。これは容易に解明さるべき問題でなく，佾幾多の研究を必要 とするは論を俟たない，余が行ったこれ迄の実験では，洞內の大型細胞が 肥满し，実質組織队で互に融合又は命体して互大細胞を生じたすのであろ うとの確信をるった．然ると本実験の成績からみれば余のこの考光は一考 を要する，そこで今のところでは他に一つの過程を考えたい，それは大型 細胞とは別な網內系細胞が刺㦸され核分裂を反覆して生じることで，之を 暗示するは核分裂像の翼常型が漸次実質組織及び牙中心に於て増数するこ とである.こ〉に余の考劣をまとめて諸賢の批判を仰ぐ次第である.

\section{IV. 結 語.}

1. 無脂肪食鸰育に括いては洞內に大型細胞を認めるも全期間を通じて 増数しない。この細胞は「ミト」の形状より固有機能が減退しているすの の様である.

2.90日飼育に括いて突如として実質組織队百大細胞が出現する．こ の細胞は大型細胞の融合によって生じたるのか, 又は别な過程をへたるの と洘える.

3. 異常核分裂像が経日的に増加する.

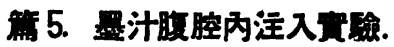

さきに行った高脂肪食投与実験飞招いて，余の注目せる大型細胞が細網 織細胞に由来するるのであることを推論した。 この大型細胞が喰食能を有 することは，既に行った諸実験によって明らかであるが，今回墨汁を腹腔 內に注入して大型細胞との他の喰食状況をしらべ, 上記の推論を更に吟味 
追及し，併せて組織像の動きをみんと本実験を企図した。

\section{I. 宽驗材料と方法.}

体重約 $100 \mathrm{~g}$ の健康ラッテに，墨 $1 \mathrm{~g}$ を生理的食塩水 $100 \mathrm{cc}$ ととかし，滤

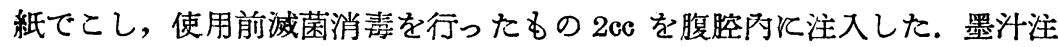
入後 30 分， 1 時間， 3 時間， 6 時間，9 時間， 12 時間， 18 時間， 24 時間 で腹腔りンパ節を取った。

固定及び染色方法等は前篇実験と同じである。

\section{II. 所見.}

注入後 30 分.リンパ洞，実質組織，芽中心とも全然墨粒子をとった細 胞はみられない。組織像にも変化はみない。

注入後 1 時間. リンパ洞の中でも特に辺䋓洞に存在する大型細胞の中に は，墨粒子を柾にとったものが若干認められる。その粒子は微細な顆粒状 を呈し，塵埃状をなして胞体內に分布している．然し中間洞の大型細胞に は墨粒子をとったものは見当らない，この様に大型細胞に墨粒子を有する あのと，そうでないものとがあるが,「ミト」は之と関係なく微細顆粒状乃 至桿状を呈している，2. 実質組織及び 3 . 牙中心とも正常時と変らない.

注入後了時間. 1. リンパ洞に㮐々濶く，大型細胞も多少の増数を示し ている.その辺緑洞にみられるものは微細乃至小顆粒状の墨粒子を稍々密 そとって抢り，同時に多数の大小種々の空胞をもっている．之に反し中間 洞にあるものの殆んどは墨粒子をとらないが，稀に微細な顆粒状の粒子を そるものが見られる．との時も亦「ミト」は小顆粒状をなして胞体內に散 在し，墨粒子と混在している．2. 実質組織に少数の喰細胞がみられるが， 墨粒子をとったものはみない。

汪入後 6 時間. 1. リンパ洞における大型細胞の増数は洘るしくないが; その殆んどのものは墨粒子をとっている，これは辺緑洞に多く，中間洞に は少ないが，細胞の大きいもの程多くの墨粒子をとって招り，大小種々の 窒胞を同時にもっている.この墨粒子はかなり大きいるのるあり，これ等 が融合し，細胞全体が真黑にみえるるのがある．而して墨粒子の大きいる のは主として辺緑洞にみられ，中間洞には小さいのを常とする．但し「ミ ト」は何れのものに於ても微細乃至小顆粒状で胞体户に竦に分布し，室胞 が多いことには変りがない，これ等大型細胞の他洞の內皮細胞が墨粒子 をとっている。この細胞にも大型と小型とあり，前者は後者より墨粒子の 喰食が多く，墨粒子そのものも大きい。2. 実質組織にては大型細胞及び喰 
細胞の増数站に墨粒子の哙食はみない，たら゙しこの部の血管腔內に初めて 墨粒子をとった細胞がみられる．3. 牙中心にみられる喰細胞には墨粒子を 認めない。

注入後 9 時間. 1. リンパ洞に打ける大型細胞の墨粒子はその攝り方に 於て 6 時間と大差はないが，全般に墨粒子をとった細胞の数は多い，この 墨粒子は大小種々の顆粒状乃至塊状をなしており，胞体內に密に存在する 篇，空胞の存在は定かでない，然し中間洞にみられる大型細胞は；辺縁洞 そ怙けるよりも墨粒子のとり方は少なく，且つとれをとつた細胞る少ない。 これら墨粒子を持つている細胞では「ミト」は墨粒子に阻まれてみえない。 次に洞队皮細胞の墨粒子喰食像は 6 時間と大差を認めない。2. 実質組織 そ扣いては喰細胞が墨粒子をとっており，その墨子は小顆粒状で，胞体に かなり密に分布している．３．これに反し牙中心の喰細胞は墨粒子をとっ ていない.

注入媵 12 時间. 1.リンパ洞のうち，辺緑洞は墨粒子を十分とったと思 われる大型細胞で殆んど充満している．これら墨粒子は大小種及の顆粒状 をなし，相融合する如く胞体队に密に分布して扣り，従って空胞の存否は

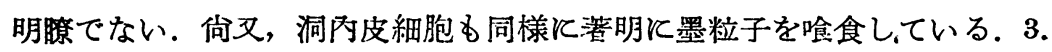
実質組織队喰細胞は墨粒子をとって和り，これらは大小種々の顆粒状乃 至塊状を呈して胞体全般にひろがっている．3. 牙中心にみられる喰細胞 はこの時初めて非常に微細な墨粒子をとっているのは注目すべきである.

注入後 18 時間及び 24 时间. 1.リンパ洞內にみられる殆んどすべての 大型細胞立に洞內皮細胞は墨粒子を十分にとっている．この墨粒子は互に 融合して胞体を满し，従って「ミト」は殆んど墨粒子によって蔽われてみ ることが困難である．勿論墨粒子の喰食状態は細胞の大いさとより種々の 段階がみられるが，一般に大型のものは小型のものよりも粒子が大きく又 多くとっている．洞內皮細胞す亦同様に豊富に喰食している．2. 実質組 䢂にす墨粒子をとった喰細胞はみられるが，このものでは洞のるのよりる 粒子がこまかい，3．牙中心の喰細胞は前例よりも墨粒子を多くとってい る.

\section{III. 總括 と考察.}

1. リンパ洞. 墨汁をラッテの腹腔內に注入すると， 1 時間後に括いて 初めて腹腔リンパ節の辺緑洞队の大型細胞飞微細な顆粒状の墨粒子を認め る. 但しこの時はその一部のるので，中間洞の大型細胞には全然これをみ ない. 然るに注入後 3 時間になると大型細胞に若干の増数がみられると共 
飞, 辺緑洞の大部分の大型細胞に微細又は小顆粒状の墨粒子がみられる. 而して中間洞の大型細胞飞は稍々括くれ，漸く注入 6 时間後に至って辺䋖 洞に近いところに現れる，叉この頃より洞邖皮細胞で墨粒子をとるものが みられる.かくて 9 時間では，墨粒子をとった細胞が増数すると共に，顆 粒状から塊状となり，胞体を充満する．但し中間洞のものは㳄緑洞のるの より墨粒子のとり方は少ない。この様に墨粒子は漸次増量してくるが,「ミ ト」はそれとは関係なく小顆粒状をなし胞体に散在している.次に洞の邖 皮細胞で墨粒子を喰食したものも亦この頃や小増数する．然し全実験を通 じ最も高眨に墨粒子喰食像の現れるのは注入後 12 時間で，この時には辺 緑洞は勿論中間洞にも墨粒子をもった大型細胞が充満し, 洞侑細胞もこ れを豊富ととっている。

2. 実質組織. 墨汁注入後 6 時間を経て初めて血管腔飞墨粒子をとった 細胞がみられるのみで，実質組織中に墨粒子をとった喰細胞の現れるのは 注入 9 時間後である.その後細胞は多くなり，且つ粒子自体も大きくなり， 遂には肥体を充満する。

3. 牙中心. 墨汁注入後 12 時間に括いて初めて非常に微細な墨粒子を とった喰細胞をみる。これより後は増数すると共に墨粒子す多く且二粒子 そのものも大きくなる.

以上の墨汁注入所見を棕合すると，リンパ節への墨汁の侵入の状況をう かごうことが出来る。即ち、恐らくは腹腔に開口していると思える輸入リ ンパ管から墨粒子はリンパ節に入り，先づその辺繶洞の大型細胞からとら れる.この粒子は熶初は微細な顆粒で塵埃様に現れるが，時間の経過と共 に小顆粒から次第に大きな顆粒となり，遂には相融合して塊状をなすに至 る.このことは大型細胞自体に墨粒子の処理能力があることを物語つてい る. かくて辺綵洞から中間洞へと喰食像が増加し，括くれて実質組織に括 ける哈細胞にる同樣の墨粒子が現れる.さて大型細胞には種々の大いさの 室胞がみられるが，之は墨粒子の有無に関係なく存在することから，墨粒 子攝取には空胞は全く関係がないことがわかる．然らば墨粒子は如何にし て大型細胞にとられるのであろろか. 祭するに本細胞の「ミト」が全期間 を通じて墨粒子とは関係なく微細又は小顆粒状として存在することからら， 墨粒子撮取には「ミト」の醉素作用は全然関係なく，全く機械的に胞体队 に攝取されるるのであるうと考えられる，但し胞体队では粒子が次第に大 きくなることは或は「ミト」がその処理に若干関与しているのかるしれな い. 次に本実験に括いて注目されるのは大型細胞灭び喰細胞以外の細胞で 
墨粒子を喰食する洞內皮細胞の態度である，この細胞は注入 6 時間後に初 めて墨粒子をとっているが、この細胞も形の大きいるの程，又洞壁より洞 內に游離せんとするもの程墨粒子は多い，即ち，大型細胞に似たるの程喰 食力が強い，このことは，さきの高脂肪食実験の所見と勘案するに大型細 胞は細網織細胞に由来し，細網織細胞は洞队皮細胞に由来するととを暗示 するすのと考える.

\section{IV. 結 語.}

1. 腹腔內に注入せられた墨汁粒子は腹腔りンパ節に 1 時間後より現れ る.

2. 墨粒子喰食能力は大型細胞, 細網織細胞乙び洞队皮細胞の順飞強 い. 従って大型細胞は細網織細胞に, 而して細網織細胞は洞内皮細胞に由 来するるのであろう・

3. 大型細胞の墨粒子は最初微細な顆粒状をなし厘埃様に散在している が，時間の経過と共に，次第に大きな顆粒となり，更に塊状となり遂には 全く胞体を占抛するに至る。この間「ミト」は墨粒子の喰食には無関係で あると思われる。

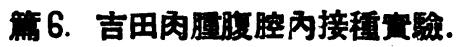

余はさきに墨斗を腹腔付に注入して墨粒子が腹腔リンパ節に和られる状 況を詳細報告した．而してリンパ節队括いて喰食能のある種々の細胞の 中でも特に洞にみられる大型細胞が真っ先に之を搯ることがわかった。 そ こで単なる異物に過ぎない墨汁に対して，病原をるった吉田肉腫接種ラッ テの腹水を選び，之を腹腔队に注入して観祭した。この試みは先に行った 慢性の経過をたど D. A. B. 実験汇打ける肝癌発生の場合と対照して， 急性の変化を来寸本実験は，腹腔リンパ節に沶ける大型細胞が如何なる防 斾機能をその細胞像の上に示すか，又逆に転移は如何にして促進されるか 甚だ興味ある問題を提供している。本实験を企欧て所似は実にこ〉にあ る.

\section{I. 寞驗材料と方法.}

体重約 $100 \mathrm{~g}$ の健康 ラッテを普通食で飼育し，腹腔队化吉田肉腫腹水 $0.5 \mathrm{cc}$ を接種し，日を追うて每日屠殺した。 大体，志田肉腫腹腔邖接種ラ ッテは吉田によれば最短 8 日，最長 24 日，本均 12 日生きる。余の实験で は每日 3 匹づ〉屠殺し14日までの材料を探取して検索した。 
固定及び染色は前実験と同様であるが，更に血液及び腹水の塗抹，MayGiemsa 氏染色標本を作製し参考に供した.

\section{II. 所見.}

吉田闪腫腹水を腹腔队付接種されたラッテの腹腔リンパ節は逐日腫大

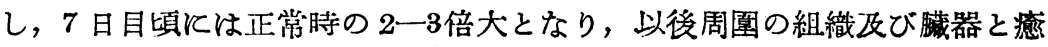
着する傾向が強くなる. 為に 10 日目以後では辰々腹腔リンパ節と周囯組 織との弁別に困難な場合がある.

2-3 日例. 1. リンパ洞のうち辺緑洞は正常と変りがないが，中間洞は 稍々执大して拉り，各種りンパ球及び赤血球がみられる. 殊飞赤血球は辺 縁洞に多く，死隇した残骸様のものが混在している，そのほかエオジン好 球の増数があり，大型細胞も亦わづかに增数している. 然し後者の內部構 造には変りなく,「ミト」は微細な顆粒状を呈して胞体內に散在し，又これ と略々同大の微細空胞多数を有している. 向辺緑洞には 3 日例において已 に少数の腫亭細胞がみられる．2. 実質組織ではリンパ母細胞の増数が特 に目立ち，その為に標本が明るく感ぜられる，この細胞の核はほよ゙円形乃 至楕円形で，核小体の大いさ及び形は種々様々で，一般に豊富な核液をる っている. こ〉には大型細胞の存在は認められないが，少数の赤血球がみ られる. 又洞に近いところでは洞に接してェオジン好球が存在し，この増 数は全般的に顕渚である．3．牙中心では明中心が跤的大きく之を圍む 暗㲄は狹い。総じて細胞の大小不同性は強いが，巽常核分裂像はみない。

4-5 日例. 1. 辺紓洞は前例に比し稍々濶く, 赤血球及びその残䯓様の ものが著るしく増加しているが，反対にェオジン好球はそれ程多くない. 又大型細胞の增数も軽度で, 形の不正なるるのが多く, その胞体內には種 々の哴食片と共に微細な顆粒状の「ミト」及び多数の小空胞を有し, 細胞 の大いさは雑多である. 佮前例に於て少数に認めた腫疾細胞は独り辺緑洞 のみならず中間洞にる増数している．2. 実質組織ではリンパ母細胞が更 に高度の増数を示し，そのあるすのは核の歪形等から腫演細胞と見て差支 えない，また，これ等の細胞間隙には赤血球が到る処にみられる程に増数 し, エオジン好球も混在する。然し大型細胞はみとめられない，3. 牙中 心はこの時全く識别出来ない。

6-8 日例. 1. 㲽緑洞は益々濶くなり，腫渲細胞の増数は癒々著明であ る. 洞邖にはこの細胞に伍して各種りンパ球乙び赤血球站に少数のェオジ ン好球が存在する. 次に大型細胞は前例より稍々増数して括り, その胞体 そ種々の核碎片と思われるるのを喰食したるのが多数認められる，但し， 
このものの「ミト」は稍々大なる顆粒状か刃は短桿状を呈し，小室胞と共 飞胞体邖飞散在する。この空胞は前例飞抢けるより著明に多いことが注目 される．2. 実質組織では腫場細胞の增数が更に著明であり，リンパ母細 胞も亦著るしく增数しているが，反面にはこの特初めて小リンパ球の減数 が顕著に現れ，これに反此例して赤血球が増数する. 大型細胞のみとめら れないことは前例と同様であるが，異常核分裂像はこの時初めて各所にみ られる。３．身中心は全く不明である.

9-11日例. 1. 㲽緑洞は更飞拉大し，殆えど腫場細胞と赤血球で充満 される。他方中間洞もこれ等の細胞で満され，そのそめ洞の附皮細胞は压 排せられ中間洞を明膫飞識別すること困難である。これら細胞の増数と反 対に大型細胞は減少し喰食片をるつたものが少数認められると過ぎない。 この時の「ミト」は桿状が主体で，顆粒状，覀鈴状及び䓕だ多数の小空胞 と混じている，2．实質組織は㱠んど腫瘍細胞で占められ，その間隙は赤 血球がこれを埋めて括り，リンパ母細胞は少なく，小リンパ球は警異的に 少数となる. 叉ェオシン好球はごく少数で，大型細胞は全然みとめられな い. 3. 牙中心は前同様全くみない。

12-14日例．1. 辺線洞は非常飞濶いところと，反対㵔るしく狹いと

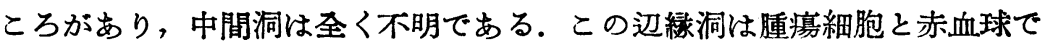
充満され，その中に多㯢白血球が混じている. 大型細胞は極めて少数みら れるに過ぎず，胞体は塩基好性碎片その他多数の空胞及び前例と大差ない 「ミト」の少数を有している，2，実質組織は殆しど腫瘍細胞とその間䏚 の赤血球で埋められ，リンパ母細胞及び小リンパ球を求めることが困難で ある.これら腫瘍細胞の核は一般に大きく且つ明調で核小体は大きい，但 乙核のこわれかっつたもの, 又細胞自体の崩㙞飞瀕したもの等が存在し, 徒って細胞，核反び核小体の大小不同性が甚だしい，この注か核分裂像が 多く，而も異常のものが多数見られる．3. 牙中心は全く不明である.

\section{III. 總括 と考案.}

1. リンパ洞. 辺緑洞，中間洞ともと急速に閵くなってゆく．然し接種 7 日目頃より実質組織內の腫場細胞の增数が顕㵔となり, 且つ又中間洞が 腫瘍細胞で満されるに反んで，一部辺緑洞は却って狹湓となるところるあ るが，12一14日頃には著明に拡大した辺緑洞の中に腫瘍細胞その他がなだ れ込む像がみられる. 次に洞內の大型細胞は接種第 1 日目より増数し， 7 日目頃最も多いが，その後は次第に減少して，12日頃には之を見出すこと が困難となる.この細胞の喰食能てついては特記の要を認めないが,「ミト」 
は空胞と平行して動く：即ち初め微細な顆粒状又は楿状を呈する「ミト」 は，增数期には顆粒状が多く且つ稍々肥厚を示する，後半期に入って減少 しはじめると桿状を呈してくる．他面茎胞は初め顆粒状「ミト」と略々同 大であるが, 次で増数と共に僅かに増大し後又徽小聜胞となる.

赤血球は 2 日目より洞队に現れ，次第に増数の一途をたどる. この赤血 球の増数に伴って白血球も増数するが, エオシン好球は 3 日が最す多く以 後次第に減数する。

其他洞円に腫痦細胞が現れる.これは接種後 3 日頃既に少数認められ， 日数と共に次第に増数し 9 日には早くも洞を満す。

2. 実質組織. 7 日頃まで増数の一途をたどったリンパ母細胞は、その 後次第に減数し，之に伴って小リンパ球も減数する．之に反して腫瘍細胞 乙び赤血球は 7 日頃から増数し始め, 実質组織は日々明調を帯びる. 佾特 筆すべきは全期間を通じてこ〉に大型細胞を認めないととである。

3. 牙中心. 明中心が大きくなり，反対に之を葍む暗款が狹くなって， 早くも4. 日頃には芽中心の識別は困難で，以後全く不明となる.

之を要するに，腹腟リパン節の洞內にある大型細胞は腹腔內に注入され た墨粒子を最先に揪取することを観祭し得た余は，本実験に於ても該細胞 に多大の期待をかけた．然るにとの反応は全く期待に反した．即ち，大型 細胞は増数して外部より侵入する赤血球，次では早急に増殖する腫瘍細胞 及びリンパ球その他を喰食するる，7日以後に打いては全く自由な大型細 胞が存在しなくなる．このことは大型細胞の産生が外来の刺㦸のあまりに 急激なるに対してその猶予のないてとを意味しているのではなかろうか.

且又, 大型細胞は赤血球その他によって閉塞されて，而も積極性飞富める 腫癍細胞が侵入し加速度的に洞及び実質組織內に於て增数する為に処理不 能の結果，自由な大型細胞の消失に拍車をかけたるのと考えられる．これ らを綜合すると大型細胞の防眐機能は早期に失われ, 吉田肉腫の㙏腔リン パ節への転移は早急に達成されるのであろう，これは前篇実験が単なる異 物であることと，本奉験が異常なる増殖力を有する徽生物であることに原 因するは明らかである。

とまれ D. A. B. そ括いては肝癌が発生し，その腹腔リンパ節には腫大 を招来するに拘らず，転移を思わせる特殊沺胞を認めることが出来ず，そ の時の組織像は脂肪過剩投与飞基因するものであることを知った．従って D. A. B. 肝癌の腹膑 リンパ節への転移はあっても余程の日数を要すると

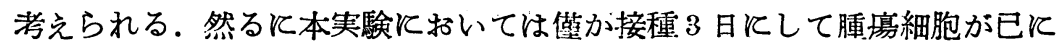


腹腔リンパ節に侵入することは，墨汁注入実験と相俟って腹水は該りンパ 節を通過してリンパ道に入ることを証明したるのと考える.

\section{IV. 結 語.}

1. 吉四肉腫接種ラッテに挌いて腫瘍細胞は巳に第 3 日に腹腔りンパ節 队侵入, 鱼激增数する.

2. リンパ洞及で実質組織內に腫瘍細胞以外に多数の赤血球をみとめる.

3. 大型細胞は早期に赤血球その他によって閉塞され, 腫瘍細胞の侵入 を容易ならしる。

4. 組織標本では実質組織邖の腫演細胞とリンパ母細胞の厳密な区別は 因難である。

稿を終るに臨み，終始御愁切なる御指導と御校閲を賜った恩師高木教授に深く感謝 すると共にっこの一篇を本研究中に逝さし愛児一雄の雷前に体ぐ・

\section{Author's Abstract.}

As it is well known, the abdominal lymph nodes are influenced by food. But this fact has not yet been shown on the cells and tissues of the lymph nodes of rats. Through the per os administration of D. A. B. 〔p-Dimethylaminoazobenzene (Butter yellow)] in olive oil a hypertrophy of the abdominal lymph nodes, resulted, increasing large cells in the sinuses and parenchyma. The giant cells seemed to form by the fusion of a number of cells. The large cells and the giant cells appeared unexpectedly not only through the administration of D. A. B., but also of olive oil as well as of high molecular palmitic acid. Through non-fat food, giant cells appeared in the parenchyma, but the large cell did not increase in number in the sinuses.

The large cells are phagocytic. This was seen after the injection of Indian ink or YOSHIDA sarcoma cells in the peritoneal cavity. The large cells, which had been too much loaded with erythrocytes, presumably could no more protect the invasion of the sarcoma cells. The large cells are in their multiplying period, judging from the behavior of the mitochondria, in full activity.

The above-mentioned large cells in the sinus are derived from reticular cells of the sinus, by losing the reticular fibres. Most of the giant cells in the parenchyma seem to be producted by the fusion of the large cells.

\section{文献.}

天野重安：血液学の基楚（昭23). - Drink:9r, C. K. a. J. M. Yoffy（西丸- 
入沢摆)：リンハ嘴, リンバ液, リンバ組織。(昭27). 一石橋悟：肝脂筫代謝にお

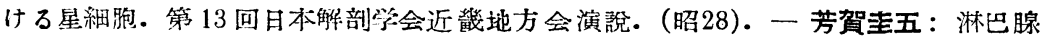
穿刺. 血討. 2 (昭23). 一広瀨俊太：高脂肪食投与に上る食慨性脂肝について. 第 39 回消化器病学会総会演繶. (昭28). 一堀井五十雄：リンバ內細胞の研㠰. 血討. 1. (昭22).一堀井五十䧸と玉木泰垔：リンバ球に関する研究. (昭26)。一長谷川 悠紀夫活加名: Changes of blood picture in the rat affected with Yoshida sarcoma. 癌 39 (1945). -- Gillman J. a. T.: Lymphomata. Clin. Proc. 8 (1949). 一松田：食慨性白血球增多時における胸管リンパの細胞像について. 日血誌. 13(昭25). 一額田弘々松尾一郎：轉移を榢らざる子宫癌局所リンバ腺の病理組織学 的所見. 概括とその意味づけ.澏 41 (1950). 一大森幸夫：細網內皮系統の細胞学

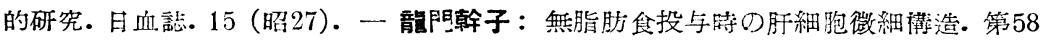
回日本解剖学会棇会演视。(昭28).一瀧川一穗：淋巴腺の障碍と再生.日微病誌. 29 (昭10). 一瀧睪敏正：罪疲所属 リンバ腺轉移に関する組織学的研究。癌 41(1950). 一 吉田富三：吉田肉腄. (昭24).

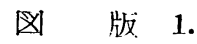

\section{A. B. 短期投與宣驗.}

因 1. 大型細胞が中间洞及び奏質にみら礼る。投与 25 日. $\times 500$.

図 2. 涩緗洞における大型細胞の増数. 投与 25 日. $\times 500$.

因 3. E大細胞加実筫にみら礼る。投与 40 日。 $\times 250$.

図 4,5,6. 大型細胞のミトコンドリア. 4 は対照, 5 は投与 25 日, 6 は投与 40 日. $\times 1500$.

\section{Short time D. A. B. administration.}

Fig. 1. Large cells in intermediate sinus and parenchyma. Administration 25 days. $\times 500$.

Fig. 2. Large cells increased in subcapsular sinus. Administration 25 days. $\times 500$.

Fig. 3. Giant cells in the parenchyma. Administraticn 40 days. $\times 250$.

Fig. 4, 5. a. 6. Mitxchondria in a large cell. 4. from a normal rat, 5. 25 days, 6. 40 days administration. $\times 1500$. 
汇版 1

腹腔リンパ節 (D.A.B. 短期投與案驗)
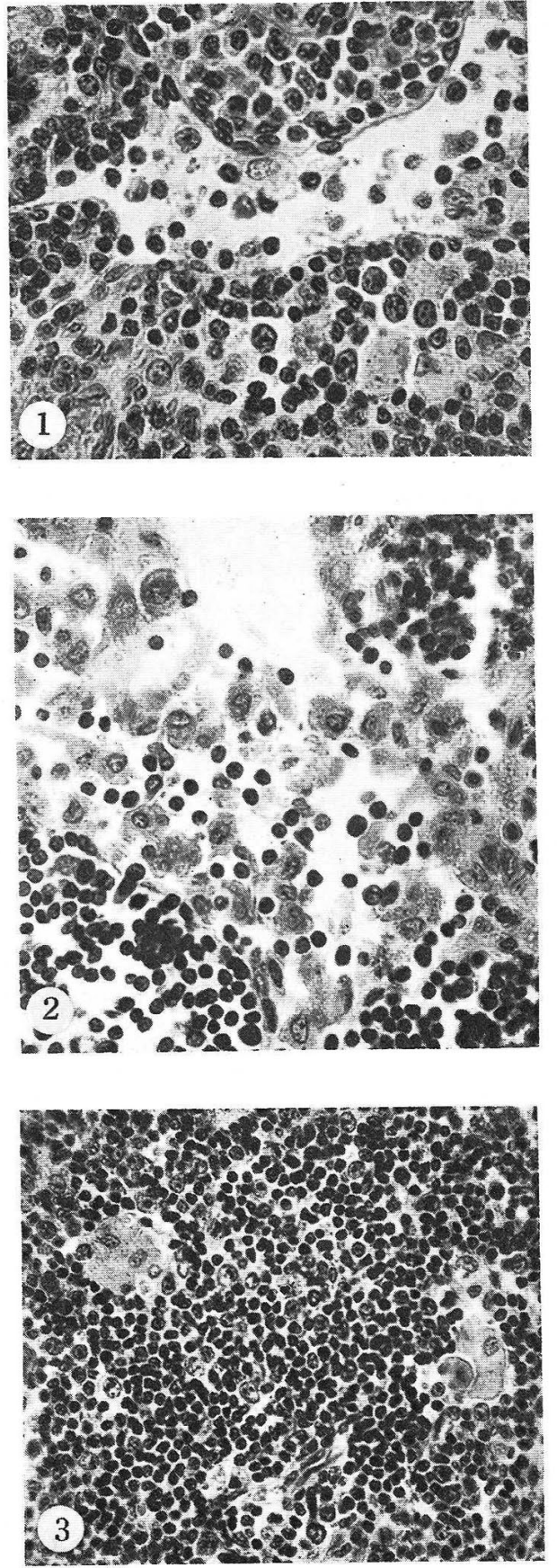

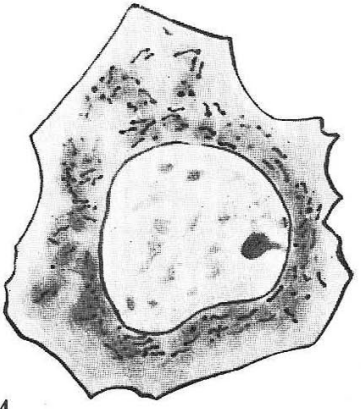

4

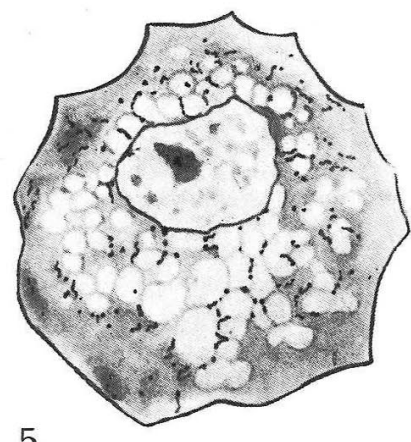

5

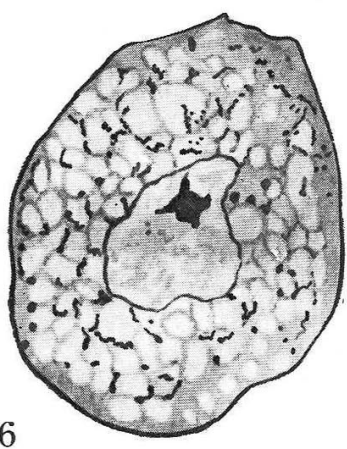




\section{海 版 2 .}

\section{A. B. 畏期投與富驗.}

汹 1. 大型細胞と甘大細胞. 投与 120 日. $\times 500$.

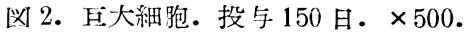

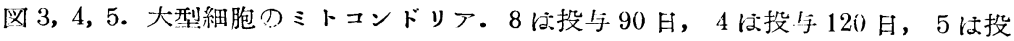
与 150 日. $\times 1500$.

図 6. 巨大細胞のミトコンドリア. 投与 150 日. $\times 1000$.

Long time D. A. B. administration.

Fig. 1. Larga cells in sinus and giant cells in parenchyma. Administration 120 days. $\times 500$.

Fig. 2. Giant cell in parenchyma. Administration 150 days. $\times 500$.

Fig. 3, 4, and 5. Mitochondria in large cells. 3. 90 days, 4.120 days, 5. 1500 days administration. $\times 1500$.

Fig. 6. Mitochondria in a giant cell. 150 days administration. $\times 1000$. 
腹腔リンパ節 (D.A.B. 長期投與実驗)
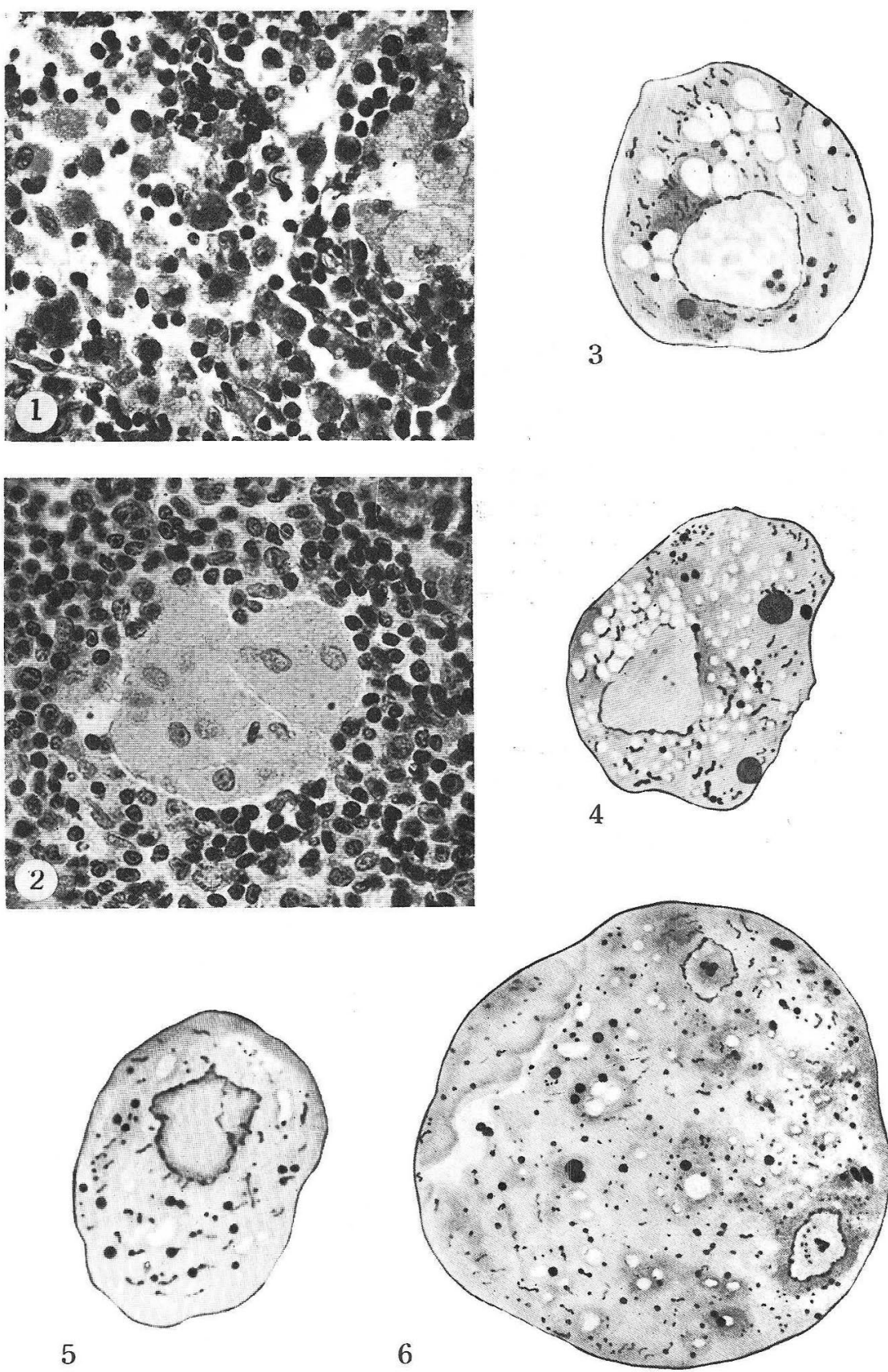


\section{湟版 3. \\ 高脂助食投與實驗.}

図 1. 洞における洞內皮細胞と大型細胞. 投与 1 逗. $\times 500$.

図 2. 大型細胞. 投与 2 週. $\times 500$.

図 3. E大細胞. 投与 4 邀. $\times 500$.

図 4, 5, 6. 大型細胞のミトコンドリア. 4 は投与 1 週， 5 は投与 2 週，6 は投与 4 淍. $\times 1500$.

\section{High fat food administration.}

Fig. 1. Large cells and endothelial cells in sinus. Administration 1 week. $\times$ 500 .

Fig. 2. Large cells. Administration 3 weeks. $\times 500$.

Fig. 3. Giant cells. Administration 4 weeks. $\times 500$.

Fig. 4, 5 and 6. Mitochondria in large cells. 4. 1 week, 5. 2 weeks, 6. 4 weeks Administration. $\times 1500$. 
凶版 3

腹肸リンパ節（高脂肪食投與案驗）
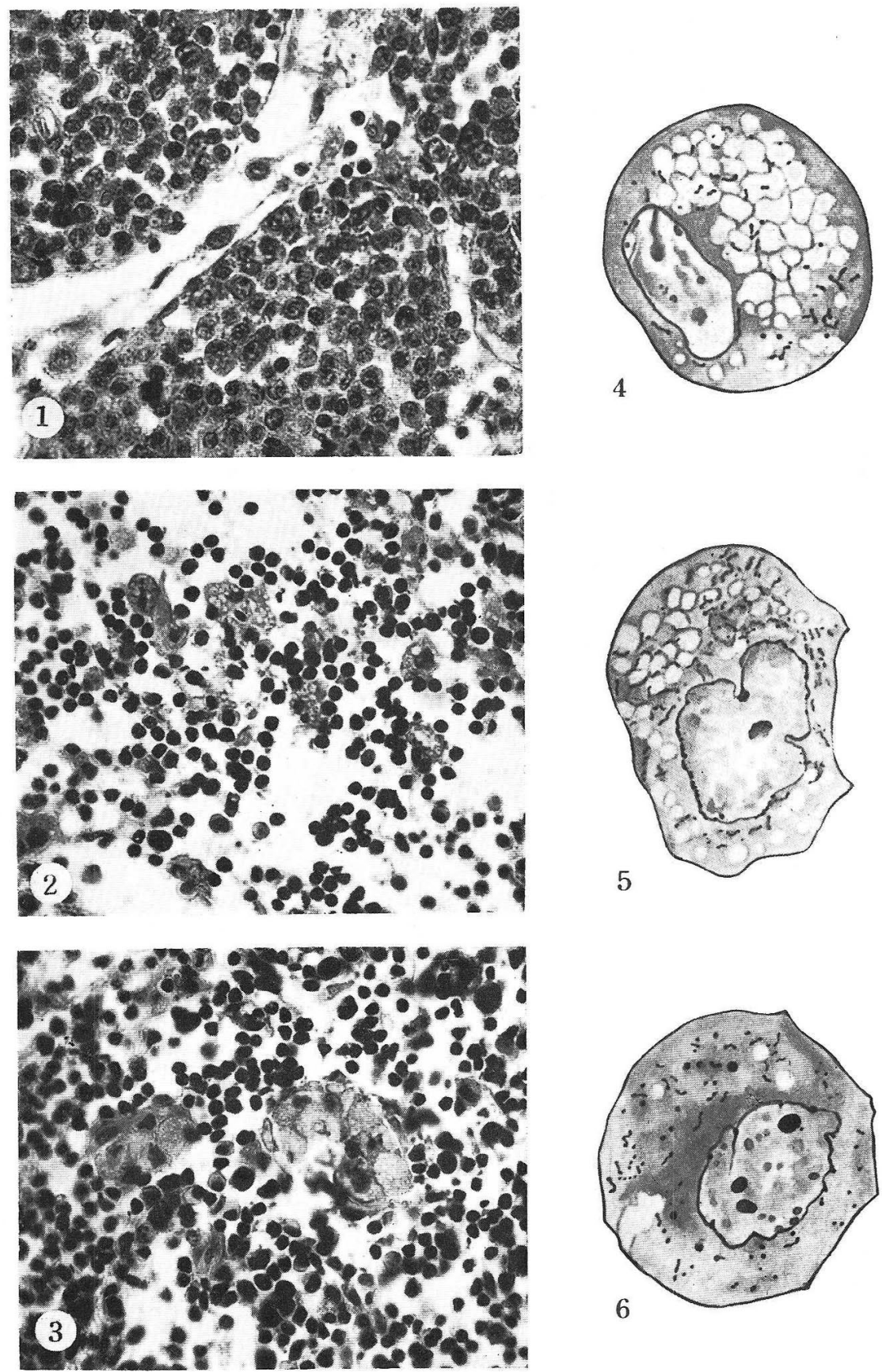


\section{源 4 .}

\section{無脂助投與量驗.}

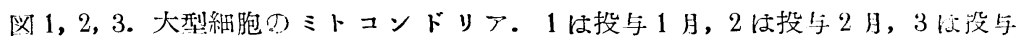
3 月. $\times 1500$.

\section{Non-fat food administration.}

Fig. 1, 2a. 3. M tochondria in large cells. 1.1 month, 2.2 months, 3.3 months Admimistration. $\times 1500$. 
腹腔リンパ節（無脂肪食投與実驗）
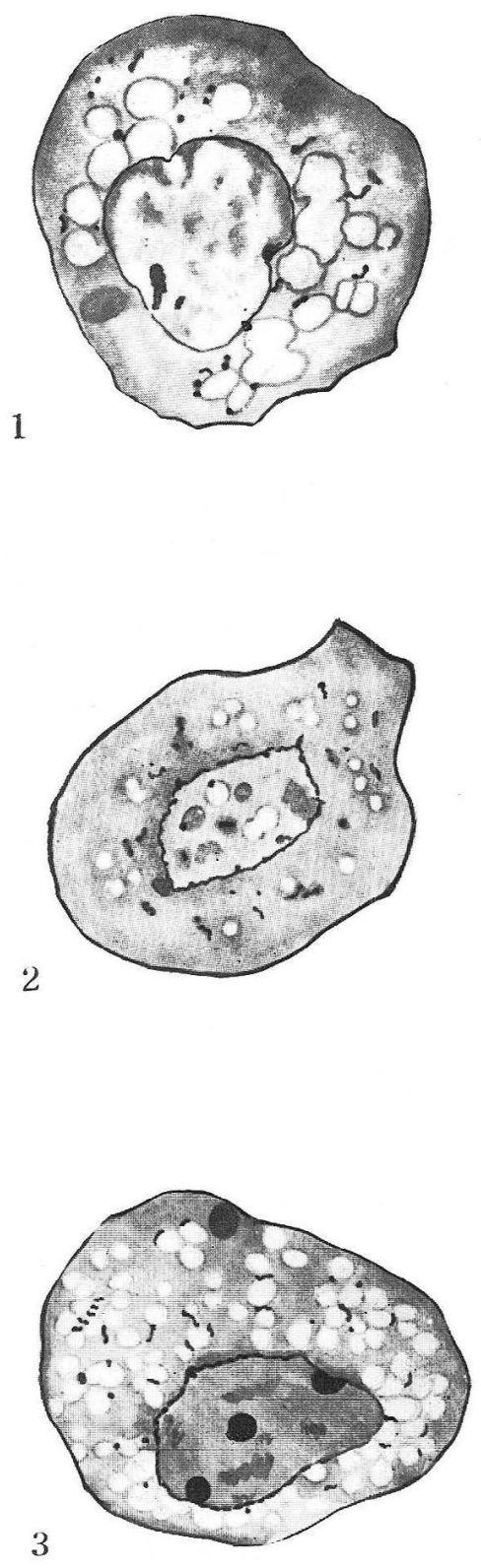


\section{海 5 . \\ 墨汁腹腔內注入責驗}

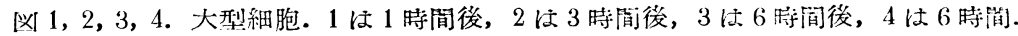
$\times 500$.

汹 5 と6. 大型細胞及び他の喰細胞. 5 は 18 時间後. $\times 500$.

\section{Indian ink injection in peritoneal cavity.}

Fig. $1,2,3$ a. 4 . Large cells. 1.1 hour, 2.3 hours, 3.6 hours, 4.6 hours after the injection. $\times 500$.

Fig. 5 a. 6 . Large cells and cther phagocytes. 5.18 hours, 6. 24 hours after the injection. 500 . 
圀版 5

腹腔リンバ節（墨汁腹㓐內泩入实驗）
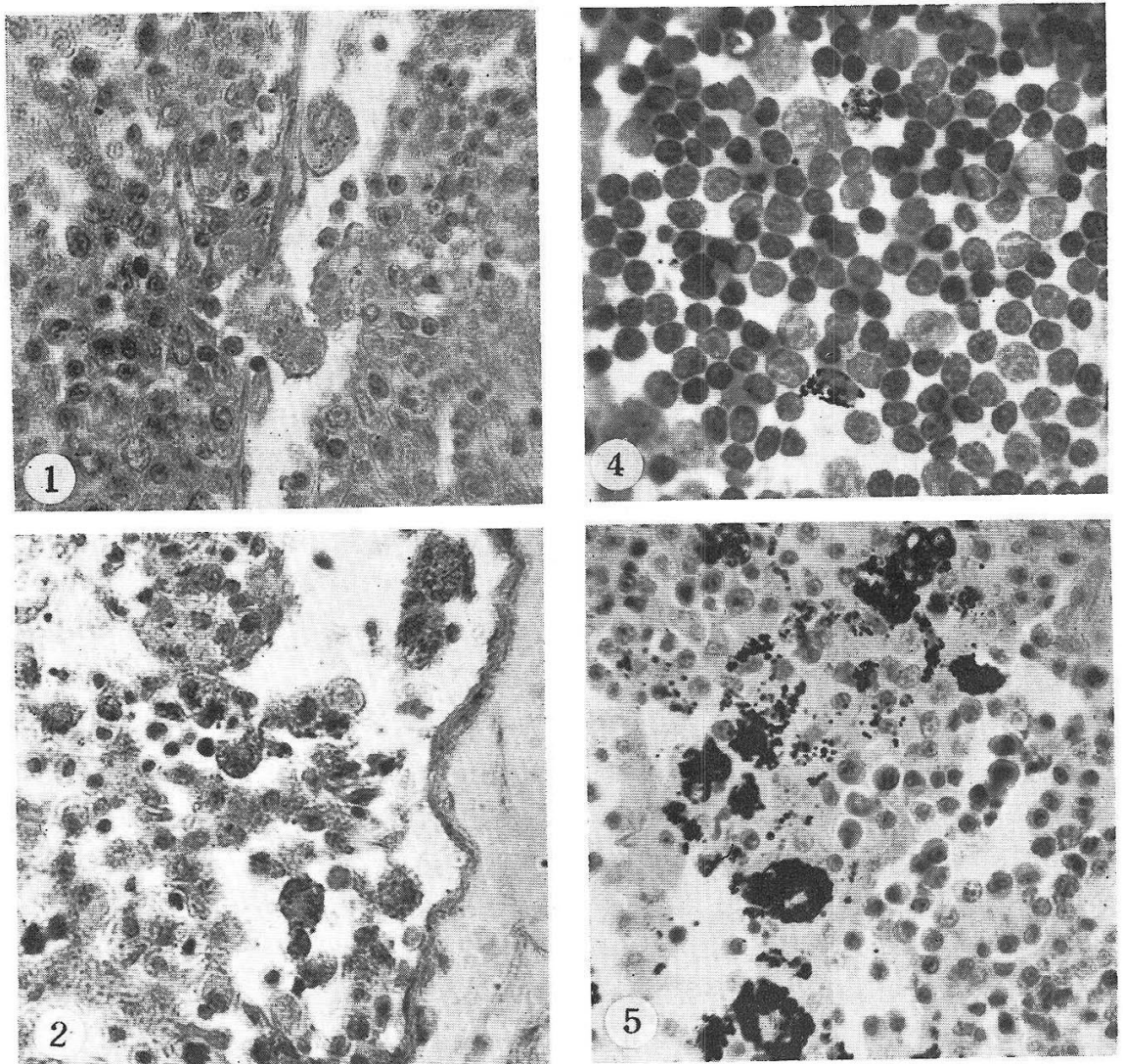

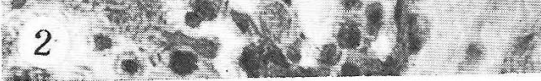
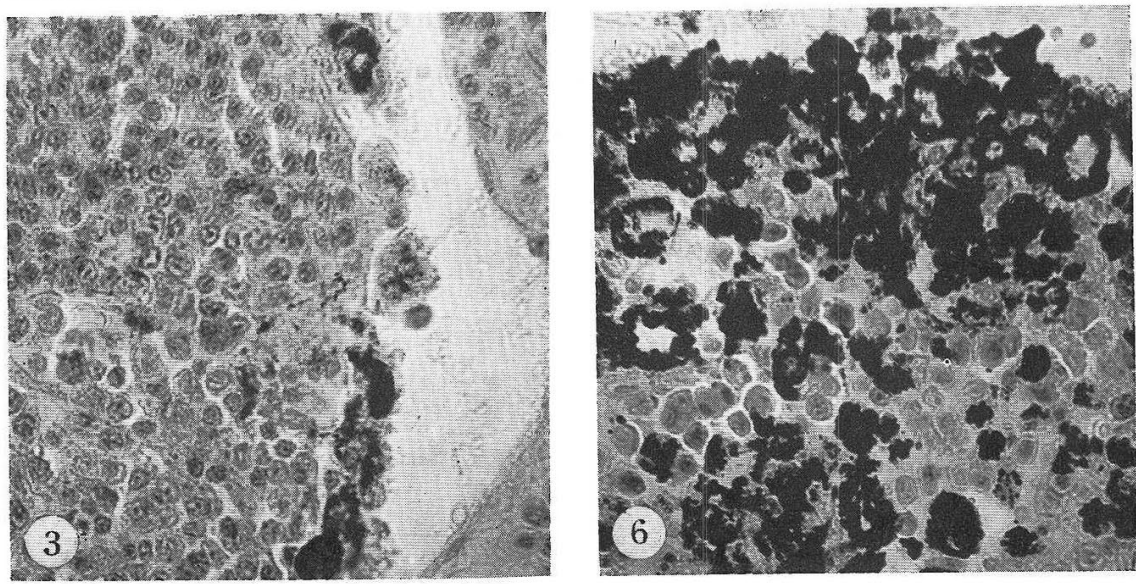
凶 版 6.

\section{吉田肉腫腹腔內接種实驗.}

淁 1 . 種 3 日目の辺緣洞.

因 2. 接種 3 日目の山间洞.

因 3. 接種 7 日目の中间洞.

図 4. 接種14日目の㲽緣洞.

YOSHIDA Sarcoma cell injection into the peritoneal cavity.

Fig. 1. Subcapsular sinus on the 3rd day after the injection.

Fig. 2. Intermediate sinus on the 3rd day after the injection.

Fig. 3. Intermediate sinus on the 7 th day after the injection.

Fig. 4. Subcapusular sinus on the 14th day after the the injection. 
図版 6

腹腔リンバ節（吉田肉腫腹腔內接種実驗）
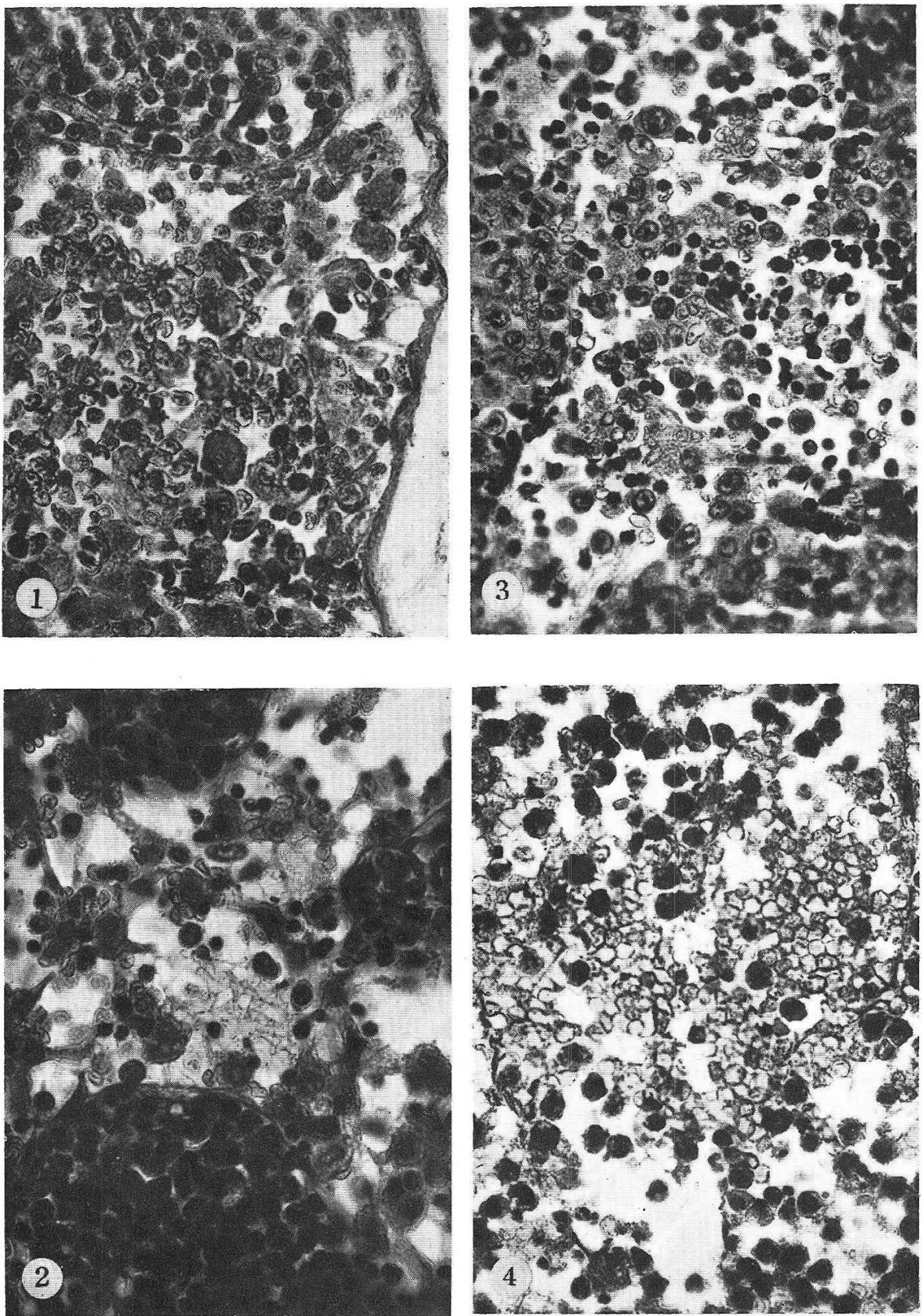